\title{
JREIET
}

\section{Using the Lexical Approach - Based Activities To Enhance EFL Preparatory Stage Students' Vocabulary Learming}

Aya El-sayed El-shahat Attya , Dr.AlyA. Qoura , Dr.Asmaa A. Mostafa Mansoura University, Faculty of Education, Department of Curriculum \& Instruction

\section{Abstract:}

$V$ ocabulary has been considered as the building block of language. EFL teachers almost always apply traditional techniques for teaching new vocabulary. The present study aimed to discover the effects of a fairly new vocabulary learning technique that is, teaching vocabulary through activities based on the lexical approach learning. This experiment utilized a Pre-post -test. Fifty students at the preparatory stage were selected through convenient sampling. They were divided into two groups of 25. The present study adopted the quasi-experimental design, using one experimental group and one control group. The experimental group was taught through the treatment i.e., studying vocabulary through collocations, whereas the control group was taught vocabulary through the traditional methods of presenting vocabulary that is suggested in the Teacher's Guide. The two groups were tested before and after the experiment. The results demonstrated that vocabulary learning through collocations eventuated in a better learning of the words than teaching them by means of classical techniques and improves learning of new words.

Keywords: Collocation, Teaching vocabulary, Vocabulary learning, Lexical approach.

\section{Introduction:}

English language is a key of exchanging information and it is a means of communication among all nations. Almost all countries have adopted English used as a compulsory subject at schools. In Egypt, English is introduced from grade one or even at pre kindergarten stage. Educational authorities have realized that English at this level becomes very important and needs much concern. English Language learning is important to generate ideas and express thoughts, improve abilities to send 
and deliver messages that are apt for different situations. It helps to improve communicative ability and help the development of language.

In the $20^{\text {th's }}$ century early decades, there were many teaching approaches and techniques which were very acceptable. The reading approach and the Grammar-translation Method were the most important language teaching approaches (Murcia1991). The Gram mar-translation Method aimed to provide learners with vocabulary which is taught through translated lists of items (Rivers1981). The Reading Approach shedded the light on expanding and mastering vocabulary than grammer.

The Direct Method introduced new vocabulary via real objects, miming, drawings and classroom explanations (Rivers1981). In The Oral Approach vocabulary and grammar were carefully chosen and graded which led to the Vocabulary Control movement which had a permanent effect on the grading of vocabulary. In Situational Language Teaching, the significance of words was not given through clarification in either the first language or the target language; it was made outwardly by means of pictures, activities and pantomime (Richards and Rodgers2001).

The Audio Lingual Method is the method where the amount of vocabulary displayed was inadequate and was selected for its simplicity (Thornbury2000). The Cognitive Approach stressed that students couldn't utilize the grammer and the functions during their communication except through following the presentation, practice and the application stages. The Communicative Approach stressed that new words are not given in isolation, but in a meaningful situation (Senel 2002).

Vocabulary has been defined in different ways. Simply its knowledge of words and its meaning. To be focused, vocabulary has other complex definitions like that of Lessard-Clouston (2013), as 'the words of a language, including single items and phrases or chunks of various words which convey a particular meaning. Words can be classified into two forms; oral and print. First, oral vocabulary is those words which people read or speak 
orally and grasp its meaning. Second, print vocabulary is the meaning grasped while reading or writing silently. These are significant differences as these words which readers know are basically oral representations.

According to Diamond \& Gutlohn (2006) vocabulary is the fully understanding words and their meanings. This definition means that without knowing words and its meanings well, there would be a lack in comprehending and using language appropriately. That's why it becomes so important to help students to recognize, speak, write and pronounce the words well to be aware of different vocabularies in various contexts.

Another complex definition about vocabulary was established by Nation (2001) which suggested that to know a word means acquiring its spoken and written form. It means that vocabulary is the backbone of language because without vocabulary, there would be no language. The word "vocabulary" broadly represents a summary of words or their combinations in a certain language. It should be noticed that words can be combined to serve as one vocabulary item. (e.g: post- office consists of two words and still expresses one idea (UR, 2000).

Additionally, Lewis (1993) believed that lexis is the building blocks of language learning which showed the importance of lexicon to language structure and how chunks are used as single items. Lexical approach is seen as the most effective way to learn English due to its importance in teaching students different word combinations and context meanings.

It stressed that native speakers use their mental lexicon to store chunks that could be used in language. Lewis (1997), suggested that teaching lexical phrases and chunks should be a part of the language teaching system. This clarified the importance of lexical phrases in any language of more grammatical structures. It led to more communication. Acquisition could be accelerated by chunking words. As seen by Lewis (1997), chunks are so important as they help language learners use it in their language.

The term collocation has been generally used to refer to a phenomenon in which certain words have the tendency to co-occur 
regularly within a language. Hence, the word lean can exclusively collocate with meat, while the word heavy has rain, meal, traffic, and smoker as possible collocates (Bahumaid, 2006).

Again, collocations refer to the meaning conveyed by adding two words together. For example, take a shower, strike a balance, armed forces instead of have a shower, make a balance and armed powers respectively. Crystal (2008) defined collocations as "the habitual co-occurrence of individual lexical items ...Collocations are, then, a type of syntagmatic lexical relation. They are linguistically predictable to a greater or lesser extent". For Lewis (2008), collocations refer to "the readily observable phenomenon whereby certain words co-occur in natural text with greater than random frequency" Thornbury (2002) treated collocations as part of a continuum of strength of word associations.

\section{Related studies:}

Following is a number of studies that addressed the effect of the lexical approach on vocabulary learning

Emamzadeh \&Zafarghandi (2016) investigated the possible effects of explicit instruction of lexical collocations. A total number of 66 Iranian university level EFL learners were selected and then were divided into experimental and control groups. The instruments were: Pretests of collocation and writing task were initially administered to both groups. The results showed that the experimental group received explicit instruction on collocations made a noticeably higher progress as compared to the control group in the posttest of collocation and writing task.

Ghezelseflou \& Seyedrezaei (2015) aimed at discovering the effects of using collocations to improve teaching vocabulary. Instruments of the study were two pre-post English vocabulary tests. Sample of the study were 60 female university students who were pre-intermediate in English language proficiency. The experimental group was taught through using collocation techniques. In contrast, control group was taught by known ways of synonyms and antonyms. Results showed that using collocations in teaching vocabulary was so beneficial as it increased learners' vocabulary and increased it. 
UÇAR's study (2015) aimed at revealing the impacts of corpus - based activities on verb- noun Collocations in EFL Classes. An experimental group and a control group were the sample of that study. They were 15 preparatory Turkish students at School of Foreign Languages, Osmaniye Korkut Ata University in turkey. Instruments of the study adopted 15 collocations taken from students' main course book which was called speak out intermediate by Pearson. Experimental group was taught by verb-noun collocation through corpus-based materials taken from COCA, while the control group was taught through a traditional way of teaching vocabulary. The findings signified that corpus-based activities had a better effect on learning vocabulary and a significant impact on verb-noun collocations in EFL classes.

Ashouri \& Rahimi study's (2014) purpose was to find the effect of corpus-based collocation on EFL learners' collocation learning. Sample of the study was 60 Iranian EFL university students who were chosen randomly in the experiment according to their scores. They were distributed to a control group and an experimental group. The study took 15 sessions in which the experimental group was taught using lexical collocation instruction and the control group received the regular work or the single-item vocabulary. Instruments used the two pre-posttests of OPT and a collocation test. Results showed the significance of using corpus- based collocation program in developing the vocabulary teaching for EFL students.

Allami \&Attar (2013) studied how teaching collocations influence the speaking ability of EFL Iranian learners. Knowing collocation and using them was also studied as well as the participants' attitudes towards using collocations. A quick placement test (QPT) was administered. Sample of the study was 40 intermediate Iranian learners who were chosen from 80 divided into an experimental group and a control one. Collocation test and collocation interview were used as pre-test in the study. Results revealed that using collocations "teaching improved the speaking ability in the experimental group and their performance in interview got increased". 
Karami \&Shooshtari (2013) aimed at questioning whether using lexical collocations helped in developing the speaking proficiency level for EFL pre-intermediate students or not. Participants of the study were 50 Iranian university students of Language Institute. The instrument was a lexical collocation. Results indicated that teaching vocabulary through lexical collocations improved the learners' speaking proficiency.

KOC (2006) studied the effect of using explicit instructions of vocabulary in collocations on improving collocational awareness of students. Participants of the study were eight groups of $160 \mathrm{EFL}$ students. They were upper- intermediate proficiency level. Four experimental groups were taught using collocation while four control groups received traditional ways of teaching. The instruments were: a vocabulary retention test and retrospective interviews. Findings showed that using collocations was highly effective.

Hsu study's goal was (2005) finding the impact of explicit collocation instruction on EFL learners listening comprehension. Participants were 34 Taiwanese university students that were invited to participate in the study. Instruments were a questionnaire and a listening comprehension test. The study took four-week period in which they studied three different types of practice. Results indicated that lexical collocation instruction was effective and was preferable to students as it increased their motivation.

Lien (2003) studied the relationship between using collocation and developing reading comprehension. A quasiexperimental study at a national university in central Taiwan was conducted. The participants were 85 Taiwanese college students. One collocation and one reading comprehension tests were administered in the pre-experimental stage. The instruments were three immediate reading comprehension tests and a questionnaire. Results showed that collocation instruction had more positive effects on the participants' reading comprehension than vocabulary instruction and no instruction.

Hsu (2002) examined how using lexical collocations would enhance the Taiwanese EFL learners' collocational proficiency in 
a one-month, intensive, business English workshop. Participants were nine Taiwanese majoring in English (7) and banking and finance. The instruments used in the study include students' writings, the teacher's class notes, a pre-test and post-test, and videotaping of subjects' interviews, presentations, and classroom activities. The results showed that focusing on lexical collocations, in both spoken and written discourses, improved students learning new collocations.

\section{Problem Statement}

Based on the literature, recommendations of other studies, the researcher's observations and the results of the pilot study, the problem of the study can be stated as follows: Second year Prep stage Students of English as a Foreign Language (EFL)

Lack adequate vocabulary which could be related to their unawareness of collocations' use, a factor that hinders them from having proflic vocabulary.

\section{Questions:}

The problem of the study includes the following questions:

1. What are the proposed activities which develop vocabulary learning?

2. What is the effectiveness of the lexical approach-based activities in enhancing EFL vocabulary learning?

\section{Purpose:}

The present study aimed at:

1. Designing proposed activities based on the lexical approach for enhancing Preparatory Stage students' EFL vocabulary learning.

2. Studying the effectiveness of the lexical approach-based activities in enhancing Preparatory Stage students' EFL vocabulary learning.

\section{Hypotheses:}

The hypothesis of the study were as follows:

There is a statistically significant difference at the 0.05 level between the mean score of the experimental group and the 
control group students on the post- administration of the vocabulary test in favor of the experimental group.

There is a statistically significant difference at the 0.05 level between the mean scores of the experimental group students on the pre-and post- administration of the vocabulary test in favor of the post one.

\section{Significance:}

This study contributed to:

1. Designing activities based on the lexical approach to help Preparatory stage students acquire and enhance EFL vocabulary.

2. Directing the attention of EFL teachers, professors and students towards the importance of vocabulary as an aid for enhancing communication skills.

3. Guiding EFL teachers in terms of the best vocabulary teaching methods to be adopted.

4. Providing a teaching technique that help students in vocabulary learning where students brain will probably have an easier time processing language in chunks or blocks rather than as single words.

\section{Delimitations:}

The present study was delimited to the following:

1. Only one aspect of the lexical approach will be investigated (Collocations).

2. A sample of the second year preparatory stage students from Kafer Azam prep. School, Elsenbilaween Directorate, Dakhliah.

3. First semester vocabulary of the English language textbook "Hello!"

4. For second year.

\section{Definition of terms: Lexical approach}

The approach stresses the necessity of using corpora to inform pedagogical materials and the importance of regularly recycling and reviewing the language taught. The Lexical 
Approach offered little guidance as to how to specify syllabus objectives, and even its methodology was not much more than an eclectic mix of procedures aimed mainly at raising learners' awareness about the ubiquity of 'chunks'.

Richards and Rodgers (2001) noted that the Lexical Approach "is still an idea in search of an approach and a methodology" (p. 138).

For the purpose of the present study The lexical approach is a method of teaching foreign languages described by. Lewis in the 1990s. The basic concept on which this approach rests is the idea that an important part of learning a language consists of being able to understand and produce lexical phrases as chunks. Students are thought to be able to perceive patterns of language (grammar) as well as have meaningful set uses of words at their disposal when they are taught in this way.

\section{Definitions of 'collocations'}

McIntosh et al(2009). Define collocations as "the way words combine in a language to produce natural-sounding speech and writing". However, there are various ways to define it and it seems that linguists and teachers have not yet agreed upon a common description. The co-occurrence of lexical items in a syntactic pattern, only restricted by general selection restrictions (also referred to as 'free/open collocation' or 'free/open combination')

For the purpose of the present study Collocations are two or more words which have a strong tendency to co-occur in a language as a prefabricated combination of two or more words in a particular context. As the inadequacy of grammar/vocabulary dichotomy is recognized, it is reasonable for collocation to play an important syllabus-generating. Collocation is defined as the readily observable phenomenon whereby certain words co-occur in actual and authentic text with greater than random frequency.

\section{Design of the Study:}

\section{Method:}

Method of the current study included the participants, instruments, design, and the procedures followed to carry out the study. 


\section{Participants:}

The Participants of the study were 50 second year students from two classes in the preparatory stage at Kafer Azam prep. School, Elsenbilaween Directorate, Dakhliah. Second year preparatory students were selected since it was the first time for them to learn vocabulary items as collocations. Each class consisted of 25 students. One class constituted the experimental group and the other represented the control group. They were taught by the same English teacher. The experiment was conducted during the first term of the academic year 2014/2015.

\section{Design:}

The present study adopted the quasi-experimental design, using one experimental group and one control group. Two classes were randomly assigned to two groups, an experimental group and a control group. The experimental group was taught through the treatment i.e., studying vocabulary through collocations, whereas the control group was taught vocabulary through the traditional method of presenting vocabulary that is suggested in the Teacher's Guide. The two groups were tested before and after the experiment.

\section{Instrument:}

The instrument used in the study was a Pre-post Vocabulary Test designed (by the researcher) .The validity and reliability of the test were established before its administration to students.

\section{The lexical approach -based activities}

Based on the literature review in chapter two, the lexical approach -based activities was constructed. Here is a brief description of these activities:

\section{Description of the activities}

The lexical approach -based activities used in this study were designed by the researcher to enhance EFL vocabulary learning of the second year of the preparatory stage students. Each collocation is presented in a simple situation where the researcher used some instructions such as" say" and" don't say" 
to introduce new collocation to complete a correct meaning. The collocation is used in a sentence to make sure that the students will get the accurate meaning of the collocation. In addition to, they also know the correct use of the collocation in English. After the collocation is presented as mentioned earlier, it is pronounced three times with three seconds in between each time to give the students the chance to repeat after the pronunciation.

The researcher designed a workbook which contains the activities to be practiced by the students through the seven units. Most of these activities are performed in pairs, groups or/and individually according to the type of each activity. All collocations in the lexical approach are presented as in the form of pictures presenting collocation, cartoon drawings on the blackboard, sentence which includes collocations, flashcards presenting collocations, worksheets for collocations and Handouts. After the collocation, students participated in some activities such as "Complete the collocation", "What does it mean?",....etc.

\section{Description of the teaching procedures}

The teaching procedures are based on the lexical approach, specifically collocations. Each unit has five lessons; students had two sessions per a week. Each session contained two lessons. The researcher presented the teaching procedures of the seven units in details. The researcher could modify, add or change the procedures according to her students' needs and class environment.

Thus, the target vocabulary for the experimental group represent vocabulary of the farm terms, pyramids pen friends collocations, work situations, the sea collocations and health and fitness. The vocabulary content of these units is specified in the students' workbook. The total number of these units' new vocabulary as specified in the students' workbook is 65 new vocabulary. When the researcher analyzed the vocabulary content of these seven units, she found that the number of the new vocabulary varies from unit to the other. Thus it was necessary to specify certain percentage of the vocabulary taken 
from each unit to be included in the vocabulary test. The test included 65 words. Each word constitutes an item in the test, so the test constitutes of 65 elements.

\section{Results}

Results were presented in terms of the hypotheses of the study:

\section{Verifying the First Study Hypothesis}

The First hypothesis stated that "There is a statistically significant difference between the mean scores of the experimental group and the control group students on the postadministration of the vocabulary test in favor of the experimental group".

T- Test for the independent samples was used to compare the mean score of the control and the experimental groups. Table (1) shows that the estimated t- value is significant at .01 level. This indicates that there is a statistically significant difference between the control and the experimental groups on the postadministration of the vocabulary test in favor of the experiment group due to the lexical approach-based activities.

Table (1)Results of the control and the experimental groups on the post-administration of the vocabulary test

\begin{tabular}{|c|c|c|c|c|c|c|c|}
\hline Skills & The group & $\begin{array}{c}\text { N.of } \\
\text { cases }\end{array}$ & Means & S.D & df & T.Value & Sig. \\
\hline \multirow{2}{*}{ Skill 1} & Experimental & 25 & 13.36 & 0.952 & \multirow{2}{*}{48} & \multirow{2}{*}{12.445} & \multirow{2}{*}{$\begin{array}{l}0.01 \\
\text { Sig. }\end{array}$} \\
\hline & Control & 25 & 6.72 & 2.492 & & & \\
\hline \multirow{2}{*}{ Skill 2} & Experimental & 25 & 7.40 & 1.658 & \multirow{2}{*}{48} & \multirow{2}{*}{9.587} & 0.01 \\
\hline & Control & 25 & 3.08 & 1.525 & & & Sig. \\
\hline \multirow{2}{*}{ Skill 3} & Experimental & 25 & 4.72 & 0.458 & \multirow{2}{*}{48} & \multirow{2}{*}{3.759} & 0.01 \\
\hline & Control & 25 & 3.48 & 1.584 & & & Sig. \\
\hline \multirow{2}{*}{ Skill 4} & Experimental & 25 & 5.00 & 0.000 & \multirow{2}{*}{48} & \multirow{2}{*}{5.196} & 0.01 \\
\hline & Control & 25 & 3.20 & 1.732 & & & Sig. \\
\hline \multirow{2}{*}{ Skill 5} & Experimental & 25 & 7.48 & 1.046 & \multirow{2}{*}{48} & \multirow{2}{*}{8.781} & 0.01 \\
\hline & Control & 25 & 4.00 & 1.683 & & & Sig. \\
\hline \multirow{2}{*}{ Skill 6} & Experimental & 25 & 13.72 & 2.525 & \multirow{2}{*}{48} & \multirow{2}{*}{14.250} & 0.01 \\
\hline & Control & 25 & 2.48 & 3.029 & & & Sig. \\
\hline \multirow{2}{*}{ Skill 7} & Experimental & 25 & 6.44 & 0.768 & \multirow{2}{*}{48} & \multirow{2}{*}{41.921} & 0.01 \\
\hline & Control & 25 & 0.00 & 0.000 & & & Sig. \\
\hline \multirow{2}{*}{$\begin{array}{c}\text { The whole } \\
\text { test }\end{array}$} & Experimental & 25 & 58.12 & 4.576 & \multirow{2}{*}{48} & \multirow{2}{*}{19.940} & 0.01 \\
\hline & Control & 25 & 22.96 & 7.536 & & & Sig. \\
\hline
\end{tabular}


Results in table (1) point to the fact that students in the experimental group mean score on post- test was higher than that of the students in the control group in each of the individual skills. Also the table shows that students mean score in the overall post-vocabulary test in the experimental group was (58.12) compared to that of the control group which was (22.96). These results indicate that the experimental group outperformed the control group on the post- vocabulary test.

The significant difference between the experimental and the control groups shown in table (1) support the effectiveness of using the Lexical approach - based activities in enhancing EFL Preparatory stage students' vocabulary. Consequently the First hypothesis of the study was verified.

Thus it could be claimed that providing the activities with the targeted vocabulary (collocations) most of the time seems to have captured the attention and curiosity of the students to learn new collocations.

\section{Verifying the Second Study Hypothesis}

The Second Hypothesis stated that" There is a statistically significant difference between the mean score of the experimental group students on the pre-and postadministration of the vocabulary test in favor of the post one."

T-test for paired samples was used to compare the difference between the mean score of the experimental group students in the vocabulary test before and after implementing the intervention (using the lexical approach -based activities) and to determine the effect of the study intervention on vocabulary learning of the experimental group.

Results in table (2) illustrate that students mean score in each individual vocabulary skill in the post -test improved $(13.36,7.40,4.72,5.00,7.48,13.72$ and 6.44) respectively. Therefore, the lexical approach -based activities were effective in enhancing EFL vocabulary learning of the experimental group students. 
Table (2)Results of the experimental group on the pre-postadministration of the vocabulary test

\begin{tabular}{|c|c|c|c|c|c|c|c|}
\hline Skills & The group & $\begin{array}{c}\text { N.of } \\
\text { cases }\end{array}$ & Means & S.D & df & T.Value & Sig. \\
\hline \multirow{2}{*}{ Skill 1} & pre - test & 25 & 5.68 & 2.982 & \multirow{2}{*}{24} & \multirow{2}{*}{12.208} & \multirow{2}{*}{$\begin{array}{l}\text { 0.01 } \\
\text { Sig. }\end{array}$} \\
\hline & post - test & 25 & 13.36 & 0.952 & & & \\
\hline \multirow{2}{*}{ Skill 2} & pre - test & 25 & 1.96 & 1.744 & \multirow{2}{*}{24} & \multirow{2}{*}{10.874} & 0.01 \\
\hline & post - test & 25 & 7.40 & 1.658 & & & Sig. \\
\hline \multirow{2}{*}{ Skill 3} & pre - test & 25 & 3.28 & 1.671 & \multirow{2}{*}{24} & \multirow{2}{*}{4.152} & 0.01 \\
\hline & post - test & 25 & 4.72 & 0.458 & & & Sig. \\
\hline \multirow{2}{*}{ Skill 4} & pre - test & 25 & 0.16 & 0.624 & \multirow{2}{*}{24} & \multirow{2}{*}{38.751} & 0.01 \\
\hline & post - test & 25 & 5.00 & 0.000 & & & Sig. \\
\hline \multirow{2}{*}{ Skill 5} & pre - test & 25 & 3.20 & 1.581 & \multirow{2}{*}{24} & \multirow{2}{*}{11.646} & 0.01 \\
\hline & post - test & 25 & 7.48 & 1.046 & & & Sig. \\
\hline \multirow{2}{*}{ Skill 6} & pre - test & 25 & 0.00 & 0.000 & \multirow{2}{*}{24} & \multirow{2}{*}{27.166} & 0.01 \\
\hline & post - test & 25 & 13.72 & 2.525 & & & Sig. \\
\hline \multirow{2}{*}{ Skill 7} & pre - test & 25 & 0.24 & 0.723 & \multirow{2}{*}{24} & \multirow{2}{*}{29.784} & 0.01 \\
\hline & post - test & 25 & 6.44 & 0.768 & & & Sig. \\
\hline \multirow{2}{*}{$\begin{array}{c}\text { The whole } \\
\text { Test }\end{array}$} & pre - test & 25 & 14.52 & 5.917 & \multirow{2}{*}{24} & \multirow{2}{*}{38.791} & 0.01 \\
\hline & post - test & 25 & 58.12 & 4.576 & & & Sig. \\
\hline
\end{tabular}

The results also indicate that the estimated t-value is significant at 0.01 level. This reflects that there is a statistically significant difference between the mean score of the experimental group pre- post administration of the vocabulary test in favor of the post- test application. Based on the results of the $\boldsymbol{t}$-test, there is an obvious improvement in the experimental group students' score on the post application of the EFL vocabulary test. This significant improvement is due to administering the lexical approach -based activities to the experimental group.

It is worth mentioning that, the previous results of the study are in line with those of Ashouri \&Reza (2016), Ghezelseflou \& Seyedrezaei (2015), Momeni (2012) Hsu (2010), KOC (2006)\& Hsu (2002) as they all affirmed that the lexical approach proved to be effective in enhancing vocabulary learning.Again, These results are in accordance with the results of the studies of Emamzadeh \&Zafarghandi (2016), Attar (2013), Shooshtari (2013), Hsu (2007), Seesink (2007), Hsu (2005)\&Lien (2003) as they confirmed the significant role of collocations in developing vocabulary learning. 


\section{The Effect Size of the lexical approach:}

In order to determine the effect size of the administration of the lexical approach -based activities the researcher calculated Eta square (Table 3). The effect size is a measure of strength of the relationship between two variables. When reporting statistical significance, it is generally recommended to report measures of the effect size.

Table (3)The Effect Size of the lexical Approach -based activities on the experimental group vocabulary Learning

\begin{tabular}{|c|c|c|}
\hline Skill & $\eta^{2}$ & Effect size \\
\hline Skill 1 & $0.86 \%$ & High \\
\hline Skill 2 & $0.83 \%$ & High \\
\hline Skill 3 & $0.42 \%$ & Low \\
\hline Skill 4 & $\mathbf{0 . 9 8 \%}$ & High \\
\hline Skill 5 & $0.85 \%$ & High \\
\hline Skill 6 & $0.97 \%$ & High \\
\hline Skill 7 & $0.97 \%$ & High \\
\hline Total & $\mathbf{0 . 9 8 \%}$ & High \\
\hline
\end{tabular}

Results in table (3) reveal that the effect size of the lexical approach - based activities on vocabulary leaning of the experimental group is high. This result can be similarly interpreted in the light of the value of $\left(\eta^{2}\right)$ as follows:

- $98 \%$ of the total variance of the experimental group students' post achievement on the vocabulary test (the dependent variable) can be attributed to the lexical approach -based activities (the independent variable). This is considered a higher percentage than the minimum -limit percentage (98\% > $15 \%)$.

Summing up the results of the t- test for paired samples indicate that there was statistically significant difference at level $<0.001^{*}$ between the mean score of the experimental group on the pre-and post-test administration and the effect side was high. So, each individual skill of the students' vocabulary skills was improved after implementing the treatment (The Lexical Approach- based Activities). Therefore, the second hypothesis can be accepted. 


\section{Conclusion:}

\section{With reference to the results of this study, the following point was concluded:}

The current study provided evidence to the effectiveness of using the lexical approach in developing and enhancing vocabulary learning. This result adds to the validity of other studies investigating similar aspects such as that of Allami, $H$ .\&Attar, E . (2013)Ashouri, S. \& Rahimi, R.(2014) ,Ashouri \&Reza (2016), Ghezelseflou \& Seyedrezaei (2015), Hsu (2010), , KOÇ (2006)\& Hsu (2002).

\section{Recommendations:}

Based on the results of the current study, the following recommendations are suggested:

1. Vocabulary learning should be a major concern in teaching EFL in our classes. It has been argued that the lack of vocabulary knowledge affects all other elements of EFL negatively.

2. The lexical approach - based activities should be used by course writing to supplement vocabulary instruction.

3. It is recommended that the suitable and sufficient lexical approach - based activities complement the textbooks of EFL in schools.

4. It is recommended that EFL teachers try to study other items of the lexical approach such as idioms and phrasal verbs.

5. It is recommended that EFL teachers try to design and develop their own lexical approach - based activities that suit their students' needs and educational levels.

6. It is recommended that EFL teachers try to adopt new techniques to teach collocations or the lexical approach in general.

\section{References}

Allami, H. \&Attar, E. (2013). The Effects of Teaching Lexical Collocations on Speaking Ability of Iranian EFL Learners. 
Online journal .Theory and Practice in Language Studies, Vol. 3, No. 6, pp. 1070-1079. Retrieved June,5, 2013 fromwww.academypublication.com/issues/past/tpls/vol03 /06/30.pdf

Ashouri, S. \& Rahimi, R.(2014) .The Impact of Corpus-Based Collocation Instruction on Iranian EFL Learners' Collocation Learning. Universal Journal of Educational Research 2(6): 470-479, 2014 Retrieved 27 November 2015 http://www.hrpub.org/download/20140525/UJER419502199.pdf

Bahumaid, S. (2006). Collocations in English-Arabic translation. Babel, 52, 133-152.

Celce-Murcia, M. (1991). Grammar pedagogy in second and foreign language teaching.TESOL quarterly, 25(3), 459-478.

Crystal. D. (2008). A dictionary of linguistics and phonetics. 6th ed. Oxford: Blackwell publishing. Retrieved 25 October 2014 from http://webcache.googleusercontent.com/search?q=cache:DxiHj Bz5NJUJ:www.academypublication.com/ojs/index.php/jltr/arti cle/download/jltr0604766777/291+\&cd=1\&hl=ar\&ct=clnk\&gl $=\mathrm{eg}$

Diamond, L. \& Gutlohn, L. (2006) Teaching vocabulary .Retrieved $\begin{array}{llll}\text { October } & 1 & 2013 & \text { from }\end{array}$ http://eltj.oxfordjournals.org/cgi/content/abstract/50/1/52

Ghezelseflou, M. \& Seyedrezaei,S .(2015). The Effect of Teaching Vocabulary through Collocations on the Vocabulary Learning of Iranian EFL Students. Journal of Language Sciences \& Linguistics. Vol., 3 (1), 9-16, 2015.Retrieved 10 November 2015 from jlsljournal.com/wpcontent/uploads/paper232.pd

Hsu, J. (2002). Development of collocational proficiency on a workshop on English for general business purposes for Taiwanese college students. Indiana University of Pennsylvania, Pennsylvania.

Hsu, L. C. (2005). The effect of lexical collocation instruction on Taiwanese college EFL learners listening comprehension, National Kaohsiung First University of Science and Technology, Taiwan. 
Karami, N. \&Shooshtari, Z. (2013) Lexical Collocation Instruction and Its Impact on Iranian Non-academic EFL Learners' Speaking Ability. Journal of Language Teaching and Research, Vol. 4, No. 4, pp. 767-776, Retrieved 27 November 2013 from

http://www.academypublication.com/issues/past/jltr/vol04/04/1 6.pdf

KOÇ, G. (2006). Developing collocational awareness. Department of Teaching English as a foreign language. Bilkent University.Ankara.Retrieved December 1,2015 from www.thesis.bilkent.edu.tr/0003109.pdf

Lessard-Clouston, M (2013). Teaching vocabulary. Alexandria, VA: TESOL International Association.

Lien, H. (2003). The effect of collocation instruction on the reading comprehension of Taiwanese college students. Indiana University of Pennsylvania, Pennsylvania .

Lewis, M. (1993). The lexical approach: the state of ELT and a way forward. London: Language Teaching Publications.

Lewis, M. (1997). Implementing the lexical approach: Putting theories into practice. London: Language Teaching Publications.

McIntosh, Colin, Ben Francis, \& Richard Poole, eds. 2nd ed. 2009. Oxford collocations dictionary for students of English (OCD). Oxford: Oxford University Press.

Nation, I. S. P. (2001). Learning vocabulary in another language. Cambridge, UK: Cambridge University Press.

Rahimi, M., \& Momeni, G. (2012). The effect of teaching collocations on English language proficiency. ProcediaSocial and Behavioral Sciences, 31, 37-42.

Richards, J.C.\& Rodgers, T. S. (2001). Approaches and methods in language teaching. Cambridge: Cambridge University Press. Rivers, W. (1981). Communicating naturally in a second language. Cambridge :Cambridge University Press.

Senel, M. (2002). A Suggested Textbook for the Students\&theTeachers of ELT Departments of the Faculties of Education for Approaches in ELT course, Ph.D.Dissertation. Ankara: Hacettepe University.Rerieved from september,27, 2013 from 
https://webcache.googleusercontent.com/search?q=cache:zs2C 2ZG5WaMJ:https://www.iasj.net/iasj\%3Ffunc $\% 3$ Dfulltext $\% 26$ aId $\% 3 \mathrm{D} 45842+\& \mathrm{~cd}=2 \& \mathrm{hl}=\mathrm{ar} \& \mathrm{ct}=\mathrm{clnk} \& \mathrm{gl}=\mathrm{eg}$

Thorburry, S. (2000).How to teach vocabulary. England:Pearson Education Limited.Ur, P., (1998). A course in language Teaching.Cabridge University Press.

UÇar, S. (2015). The Effect of Corpus-based Activities on VerbNoun Collocations in EFL Classes. Online Journal of Educational Technology $-\operatorname{vol}(14)$ issue 2. Retrieved 10 November 2015 from http://webcache.googleusercontent.com/search?q=cache:p 9pvz5wPISQJ:www.tojet.net/articles/v14i2/14222.pdf+\&c $\mathrm{d}=1 \& \mathrm{hl}=\mathrm{ar} \& \mathrm{ct}=\mathrm{clnk} \& \mathrm{gl}=\mathrm{eg}$

UR, P. (2000). A Course in Language Teaching: Practice and theory. Cambridge:Cambridge University Press, 2000. ISBN0521-44994-4

Zafarghandi, A, Emamzadeh, s. (2016). The Effect of Teaching Lexical Collocations on Iranian EFL Learners' writing Ability: Focusing on the Appropriate Use of Collocations. Journal of Applied Linguistics and Language Research. Vol 3, No 5. Retrieved 27 November 2016 from http://www.jallr.com/index. php/JALLR/article/view/375 
